\title{
Perlindungan Indikasi Geografis terhadap Damar Mata Kucing (Shorea Javanica) sebagai Upaya Pelestarian Hutan (Studi di Kabupaten Pesisir Barat Propinsi Lampung)
}

\author{
Ahmad Moelyono Anasis, Mieke Yustia Ayu Ratna Sari \\ Fakultas Ilmu Sosial dan Politik dan Fakultas Hukum \\ Universitas Tulang Bawang Lampung \\ Jl. Gajahmada No. 34 Kotabaru Bandar Lampung \\ miekeius@gmail.com
}

\begin{abstract}
Mata Kucing resin (Shorea Javanica) is the main commodity of Pesisir Barat Regency which is wellknown worldwide and is one of the best resin types in the world. Mata Kucing resin has the potential to be a Geographical Indication, but it has not yet been registered to the Directorate General of Intellectual Property Rights. This research discusses the obstacles why Mata Kucing resin (shorea javanica) has not been registered as a Geographical Indication and the efforts of the government of Pesisir Barat Regency to preserve Mata Kucing resin (shorea javanica) as a way of preserving its forest area. This research employed normative-empirical approach (applied law research). The conclusion based on the research finding is that neither the citizens nor government of Pesisir Barat Regency have fully understood the benefits of registering Geographical Indication so that they have not prepared any requirements to register Mata Kucing resin. The effort to preserve resin is through limiting the cutting of Mata Kucing resin trees in Lampung Province as stated in the decree of Forestry Minister Number S.459/Menhut-VI/2010.
\end{abstract}

Keywords: Mata kucing resin, geographical indications, intellectual property rights

\begin{abstract}
Abstrak
Damar mata kucing (shorea javanica) sebagai komoditi unggulan Kabupaten Pesisir Barat dikenal oleh dunia internasional dan merupakan jenis damar terbaik di dunia. Damar Mata Kucing memiliki potensi sebagai Indikasi Geografis, namun sampai saat ini belum didaftarkan ke Direktorat Jenderal Hak Kekayaan Intelektual. Penelitian ini mengkaji tentang kendala Damar Mata Kucing (shorea javanica) belum didaftarkan sebagai indikasi geografis dan upaya Pemerintah Kabupaten Pesisir Barat untuk melindungi damar mata kucing (shorea javanica) sebagai wujud pelestarian kawasan hutan. Penelitian ini menggunakan pendekatan normatif-empiris (applied law research). Kesimpulan dari hasil penelitian ini adalah masyarakat dan Pemerintah Kabupaten Pesisir Barat belum memahami mengenai manfaat dari pendaftaran Indikasi Geografis sehingga belum mempersiapkan persyaratan pendaftaran Damar Mata Kucing. Upaya yang dilakukan untuk melindungi damar melalui pembatasan penebangan pohon Damar Mata Kucing di Provinsi Lampung melalui Surat Keputusan Menteri Kehutanan Nomor S.459/Menhut-VI/2010.
\end{abstract}

Kata kunci : Damar mata kucing, indikasi geografis, hak kekayaan intelektual 


\section{Pendahuluan}

Keberadaan Hak Kekayaan Intelektual (HKI) dalam hubungan antar manusia dan antar negara merupakan sesuatu yang tidak dapat dipungkiri. Keberadaannya senantiasa mengikuti dinamika perkembangan masyarakat itu sendiri. Begitu pula halnya dengan masyarakat dan bangsa Indonesia yang mau tidak mau bersinggungan dan terlibat langsung dengan masalah HKI.Permasalahan mengenai Hak Kekayaan Intelektual akan menyentuh berbagai aspek dalam kehidupan manusia,seperti aspek teknologi, industri, sosial, budaya, dan berbagai aspek lainnya. Namun, aspek terpenting jika dihubungkan dengan upaya perlindungan bagi karya intelektual adalah aspek hukum. Hukum diharapkan mampu mengatasi berbagai permasalahan yang timbul berkaitan dengan Hak Kekayaan Intelektual tersebut. Hukum harus dapat memberikan perlindungan bagi karya intelektual baik yang berasal dari hasil kreasi dan cipta manusia maupun dari alam, sehingga mampu mengembangkan daya kreasi masyarakat yang akhirnya bermuara pada tujuan berhasilnya perlindungan Hak Kekayaan Intelektual.

Arus globalisasi memberikan kontribusi bagi perkembangan hukum Hak Kekayaan Intelektual. Pengaruh teknologi informasi telah menjadikan kegiatan di sektor perdagangan meningkat secara pesat. Hal itulah yang mendorong tumbuh dan berkembangnya Indikasi Geografis dalam ranah kekayaan intelektual. Indikasi Geografis merupakan salah satu rezim dari HKI yang berhubungan dengan nama dagang yang dilekatkan pada kemasan suatu produk dan berfungsi menunjukkan asal tempat produk tersebut. Asal tempat itu mengisyaratkan kualitas produk sangat dipengaruhi oleh tempat asalnya, sehingga produk itu bernilai unik di benak masyarakat, khususnya konsumen yang tahu bahwa tempat asal itu memang mempunyai kelebihan khusus dalam menghasilkan suatu produk. ${ }^{1}$

Ditinjau dari segi sifat dan karakteristik perlindungannya, indikasi geografis berbeda dengan rezim HKI lainnya, yang pada umumnya bersifat individualistik. Perlindungan indikasi geografis bersifat kolektif yang dimiliki

1 Miranda Risang Ayu, Memperbincangkan Hak. Kekayaan Intelektual : Indikasi Geografis, PT. Alumni ,Bandung, 2006, hlm.1 
oleh masyarakat pemegang hak. Karakteristik perlindungan indikasi geografis yang demikian sejalan dengan nilai-nilai ketimuran dan ke-Indonesiaan, yang lebih menghargai kepemilikan bersama daripada kepemilikan individu. Objek dari indikasi geografis adalah produk yang dihasilkan oleh suatu wilayah tertentu yang memiliki ciri khas berbeda daripada wilayah lainnya. Suatu objek/produk mendapatkan perlindungan indikasi geografis apabila mempunyai potensi yang menimbulkan hasil budi daya nabati maupun hayati bercirikan geografis di mana produk itu berada.

Indikasi geografis dianggap suatu hal penting di beberapa negara, misalnya negara di kawasan Asia yang telah mulai mengaplikasikan perlindungan indikasi geografis untuk produk-produk unggulan spesifik lokasi seperti di Cina (teh Long Jin, anggur beras kuning Shaoxin dan lain-lain), di Vietnam (saus ikan Phu Quoc, jeruk gelundung Doan Hung), dan di Thailand (beras aromatik Buriram). Indonesia memiliki banyak produk pertanian, perikanan, dan kerajinan unggulan spesifik lokasi yang telah memiliki reputasi baik, sehingga produk-produk tersebut perlu mendapatkan perlindungan hukum serta sekaligus sebagai sarana untuk promosi dalam pemasarannya. Produkproduk yang berpotensi tersebut antara lain kopi Toraja, pala Banda, kopi Kintamani, jeruk gelundung Nambangan, lada putih Muntok, ubi Cilembu, batik Pekalongan, jenang Kudus, dan lain sebagainya. Produk-produk spesifik lokasi tentu saja sangat lekat dengan pengetahuan tradisional dan kearifan lokal. ${ }^{2}$

Provinsi Lampung mempunyai banyak potensi daerah unggulan yang berasal dari keanekaragaman budaya dan sumber daya alamnya, diantaranya kopi, karet, kelapa sawit, lada hitam, getah damar, dan lain sebagainya. Komoditi tersebut beberapa diantaranya masuk klasifikasi sebagai Indikasi Geografis, namun hanya satu komoditi yang telah memiliki sertifikasi Indikasi Geografis yaitu Kopi Robusta Lampung dengan no register ID G 000000026 yang didaftarkan pada 13 Mei 2014. Indikasi Geografis Kopi Robusta Lampung didaftarkan oleh Masyarakat Indikasi Geografis Kopi Robusta Lampung (MIGKRL).

${ }^{2}$ http://www.disbun.baliprov.go.id, diakses tgl.26 April 2015 
Jenis Damar Mata Kucing atau yang dalam bahasa latinnya shorea javanica adalah salah satu jenis damar yang langka di dunia dan satu-satunya di Indonesia. Perkebunan damar yang berada di Kabupaten Pesisir Barat ini adalah perkebunan rakyat yang diusahakan secara turun-temurun, bahkan ada yang mencapai usia 70 tahun dan kawasan Taman Nasional Bukit Barisan Selatan (TNBBS). Data dari Dinas Kehutanan Propinsi Lampung luas repong ${ }^{3}$ damar yang ada di Krui29.000 Ha. Repong damar tersebar di hampir seluruh wilayah Pesisir Barat, yakni di Kecamatan Lemong, Pahmungan, Pesisir Utara, Karya Penggawa, Pesisir Tengah, Pesisir Selatan, Ngambur, Bengkunat dan Bengkunat Belimbing terdapat hutan damar. Dalam tatanan kehidupan masyarakat Krui, repong damar menjadi bagian yang tak terpisahkan bahkan menjadi bagian dari jati diri masyarakat ini. Dahulu bahkan repong damar menjadi simbol status kepemilikan tanah oleh masyarakat Krui dimana tanah hutan yang sudah dibuka oleh seseorang tidak akan bisa lagi digugat oleh yang lainnya bila tanah bekas hutan tersebut sudah berwujud repong damar. ${ }^{4}$

Getah damar menjadi komoditas unggulan Lampung dari Hasil Hutan Bukan Kayu (HHBK). Budidaya damar punya dua manfaat sekaligus yaitu pelestarian hutan dan ekonomi. Getah damar mata kucing banyak digunakan untuk bahan emulsi (campuran) pewarna, cat, tinta, aromatik untuk makanan, bahkan juga untuk kosmetik dan lain sebagainya. Damar menjadi salah satu sumber pendapatan utama bagi masyarakat di Pesisir Barat, terdapat beberapa keunggulan damar dibandingkan dengan komoditi lainnya yaitu masa panen bisa dilakukan minimal 30 sampai dengan 40 hari untuk mendapatkan kualitas yang unggul, namun getah damar bisa juga dipanen 1 minggu apabila masyarakat membutuhkan dana untuk menutupi kebutuhan sehari-hari. Komoditas lainnya seperti kopi maupun lada hanya dapat dipanen 1 tahun sekali.

Repong damar yang ada di Kabupaten Pesisir Barat mengalami degradasi luas areal lahan yang akan mengancam kelestarian pohon damar. Di beberapa kecamatan bahkan repong damar sudah banyak berkurang, misalnya Kecamatan

${ }^{3}$ Repong adalah istilah masyarakat Krui untuk menyebut kebun milik mereka yang berisi aneka tanaman, seperti lada, kopi, petai, durian, nangka, cempedak, duku, juga tumbuhan kayu hutan. Karena pohon damar mendominasi, maka kebun yang menyerupai hutan alam itu disebut Repong Damar.

${ }^{4}$ http://epetani.deptan.go.id/berita/potensi- $\%$ E2 $\% 80 \% 9$ Cgetah-damar-mata-kucing $\%$ E2\% $\% 0 \% 90$ Dkab-lampung-barat-7744, diakses tgl. 20 januari 2014. 
Karya Penggawa dan Pesisir Tengah. Kondisi tersebut disebabkan oleh pohon tumbang akibat angin puting beliung maupun penebangan pohon damar dipicu tingginya permintaan dan harga jual kayu damar yang merupakan jenis meranti. Fluktuasi harga getah juga sangat mempengaruhi rendahnya minat masyarakat untuk mempertahankan repong damar yang dimilikinya.

\section{Rumusan Masalah}

Permasalahan dalam penelitian ini antara lain, pertama: apakah kendala damar mata kucing (shorea javanica) belum didaftarkan sebagai indikasi geografis? Kedua, apakah upaya yang dilakukan Pemerintah Kabupaten Pesisir Barat untuk melindungi Damar Mata Kucing (shorea javanica) sebagai wujud pelestarian kawasan hutan?

\section{Tujuan Penelitian}

Tujuan penelitian ini adalah untuk mengetahui : pertama, kendala damar mata kucing (shorea javanica) belum didaftarkan sebagai indikasi geografis. Kedua, upaya yang dilakukan Pemerintah Daerah khususnya Kabupaten Pesisir Barat untuk melindungi damar mata kucing (shorea javanica) sebagai wujud pelestarian kawasan hutan.

\section{Metode Penelitian}

Penelitian ini menggunakan pendekatan normatif-empiris (applied law research). Penelitian hukum normatif-empiris (terapan) bermula dari ketentuan hukum positif tertulis yang diberlakukan pada peristiwa hukum in concreto dalam masyarakat, sehingga dalam penelitiannya selalu terdapat gabungan dua tahap kajian, yaitu :5 a) Tahap pertama adalah kajian mengenai hukum normatif yang berlaku, b) Tahap kedua adalah penerapan pada peristiwa in concreto guna mencapai tujuan yang telah ditentukan. Hasil penerapan akan menciptakan 
pemahaman realisasi pelaksanaan ketentuan-ketentuan hukum normatif yang dikaji telah dilaksanakan secara patut atau tidak.

Penelitian hukum melalui pendekatan normatif-empiris membutuhkan data primer berupa wawancara mendalam (in-depth interview), ${ }^{6}$ yaitu proses memperoleh keterangan untuk tujuan penelitian dengan cara tanya jawab sambil bertatap muka antara pewawancara dengan responden atau orang yang diwawancarai, dengan atau tanpa menggunakan pedoman (guide) wawancara di mana pewawancara dan informan terlibat dalam kehidupan sosial yang relatif lama. Narasumber penelitian diantaranya Dinas Kehutanan Propinsi Lampung, Dinas Perkebunan dan Kehutanan Kabupaten Pesisir Barat, Kanwil Hukum dan HAM Propinsi Lampung, dan petani dan kelompok tani yang ada di Kecamatan Pesisir Tengah Krui desa Pahmungan, Pugung Tampak, Karya Penggawa Desa Penengahan,Kecamatan Pesisir Selatan desa Bengkunat. Pemilihan lokasi penelitian didasarkan pada informasi awal yang diperoleh dari Dinas Kehutanan Propinsi Lampung mengenai keberadaan repong damar di wilayah Kabupaten Pesisir Barat.

Data sekunder dalam penelitian ini terdiri dari bahan hukum primer yang bersumber dari peraturan perundang-undangan Republik Indonesia terkait Hak Kekayaan Intelektual khususnya Undang-Undang No.15 Tahun 2001 tentang Merek, Peraturan Pemerintah No. 51 Tahun 2007 tentang Indikasi Geografis, serta peraturan lainnya, bahan hukum sekunder (hasil penelitian dan karya ilmiah terkait kekayaan intelektual khususnya indikasi geografis), dan bahan hukum tersier (kamus dan ensiklopedia). Data yang diperoleh selanjutnya dianalisis secara kualitatif.

\section{Hasil Penelitian dan Pembahasan}

\section{Indikasi Geografis di Indonesia}

Indikasi geografis merupakan bagian dari Kekayaan Intelektual yang bersifat komunal, karena kepemilikan dari indikasi geografis tidak bisa dikuasai

${ }^{6}$ M. Hariwijaya, Metodologi dan Teknik Penulisan Skripsi, Tesis, dan Disertasi, Penerbit Elemantera Publishing, Yogyakarta, 2007, hlm. 73-74 
oleh perorangan. Konsep indikasi geografis menunjuk pada asal, kualitas, dan karakteristik suatu barang, yang dipengaruhi oleh daerah asal barang yang bersangkutan atau manusia atau keduanya. Ciri khas produk indikasi geografis biasanya hanya ada di daerah tersebut, dan tidak bisa tumbuh atau dibuat di daerah lain. Pada prinsipnya komoditas atau produk yang ada di satu daerah pasti berbeda dengan daerah lain, karena dipengaruhi oleh karakteristik lingkungan alam dan manusianya. Adanya pendaftaran indikasi geografis, maka akan melindungi produk lokal agar tidak dimanfaatkan secara melawan hukum oleh pihak asing yang akhirnya merugikan masyarakat lokal.

Peran perlindungan Indikasi Geografis sangat penting. Masyarakat produsen lokal membutuhkan perlindungan hukum terhadap nama asal produk agar tidak dipergunakan oleh pihak lain untuk melakukan persaingan tidak sehat. Semakin kuatnya persaingan pada era pasar global di beberapa dekade belakangan ini, semakin pentingnya Indikasi Geografis yang dapat melindungi suatu ciri khas produk.7 Indikasi Geografis dapat digunakan untuk melindungi berbagai produk dalam bentuk alam, makanan, kerajinan, dan berbagai produk yang dihasilkan dari pengetahuan asli yang mengandung kekhasan dari suatu wilayah. Indonesia memiliki hasil sumber daya alam sangat berlimpah sehingga perlu perhatian menyangkut Indikasi Geografis. ${ }^{8}$

Dari segi definisi, Indikasi Geografis adalah :

"A Geographical Indication is a sign used on goods that have specific geographical origin and possess qualities or a reputation that are due to that place of origin. Most commonly, a geographical indications consists of the name of the place of origin of the goods. Agricultural products typically have qualities that derive from their place of productionand are influence by specific local factors, such as climate and soil."9

Dari pengertian di atas dapat diuraikan ciri atau unsur-unsur pokok indikasi geografis sebagai berikut: 1. Sebagai tanda yang diambil dari nama daerah yang merupakan ciri khas suatu produk atau barang yang diperdagangkan; 2. Sebagai tanda yang menunjukkan kualitas atau reputasi

${ }^{7}$ Ellyanti dkk, "Analisis Indikasi Geografis Kopi Arabika Gayo Ditinjau Dari Rencana Tata Ruang Wilayah Kabupaten”, Jurnal Agrista Vol. 16 No. 2 2012, hlm. 47

${ }^{8}$ Yeti Sumiati dkk, "Kajian Yuridis Sosiologis Mengenai Indikasi Geografis Sebagai Sumber Pendapatan Asli Daerah (PAD)”, Mimbar, Vol. 24, No.1, Januari 2008, hlm. 83.

${ }^{9}$ http://www.wipo.int/geo indications/en/about.html, diakses tanggal 10 Maret 2015. 
produk atau barang yang bersangkutan; 3. Kualitas barang tersebut dipengaruhi oleh alam, cuaca dan tanah di daerah yang bersangkutan.

Ruang lingkup yang dilindungi oleh indikasi geografis bukan saja berupa tanah tempat tumbuh produk tersebut, namun dapat juga berupa aspek-aspek yang berhubungan dengan lingkungan alam serta faktor manusia yang tidak terpisahkan dengan lingkungannya. ${ }^{10}$ Produk yang mempunyai potensi indikasi geografis beraneka ragam, tidak harus berupa hasil pertanian asalkan memenuhi kriteria indikasi geografis, diantaranya hasil pertanian, bahan pangan, hasil kerajinan tangan, atau bahan lainnya, termasuk bahan mentah dan/atau hasil olahan baik yang berasal dari hasil tambang, berasal dari daerah tertentu dan memiliki kekhususan.

Indikasi geografis pada dasarnya memuat empat hal yaitu : Penentuan wilayah penghasil produk, spesifikasi metode produksi, spesifikasi kualitas produk, serta nama dan spesifikasi tertentu yang membedakan dari produk sejenis. Ruang lingkup terlaksananya indikasi geografis diatur khusus dalam PP No. 51 Tahun 2007 Tentang indikasi Geografis Pasal 2 meliputi: 1) Tanda meliputi nama tempat atau daerah yang menunjukkan asal tempat dihasilkannya barang yang dilindungi oleh indikasi geografis; 2) Barang dapat berupa hasil pertanian, produk olahan, atau hasil kerajinan tangan; 3) Tanda tersebut dilindungi sebagai indikasi geografis apabila didaftarkan di Dirjen HKI; 4) Indikasi geografis terdaftar tidak dapat berubah menjadi milik umum.

\section{Damar Mata Kucing (shorea javanica) di Kabupaten Pesisir Barat Propinsi Lampung}

Damar Mata Kucing (shorea javanica) merupakan spesies penghasil resin, dikenal sebagai getah damar, yang bernilai tinggi sebagai bahan baku industri cat, tinta, bahan campuran minuman, sebagai anti rayap, anti jamur, serta bahan pangan tambahan. Potensi ekonomi getah damar dikenal sejak lama. Perdagangan damar berlangsung sejak awal abad ke-10 di Cina dan negara-

${ }^{10}$ I Gede Agus Kurniawan, Pengaturan Penghentian Pemakaian Indikasi Geografis Pada Merek Terdaftar Oleh Pihak Lain yang Tidak Berhak. (Studi Komparatis Beberapa Negara), Tesis, Universitas Udayana, Denpasar, 2013, $\operatorname{hlm} .8$ 
negara di Asia Tenggara, yang kemudian berkembang ke Eropa dan Amerika pada awal abad ke-19. ${ }^{11}$

Damar Mata Kucing, menurut sejarahnya, berasal dari Propinsi Sumatera Barat dan Propinsi Sumatera Selatan (daerah Martapura). Warga masyarakat yang tinggal di daerah Krui merupakan keturunan nenek moyang mereka yang berasal dari daerah Martapura Sumatera Selatan. Pada zaman Belanda, masyarakat Krui telah melakukan perdagangan hasil hutan seperti buah-buahan, gading, rotan, serta getah damar mata kucing. Damar Mata Kucing merupakan komoditas yang paling banyak diminta pasar, oleh karenanya kegiatan budidaya pohon damar mulai dikembangkan. ${ }^{12}$

Damar adalah resin yang dihasilkan oleh genus Shorea, Hopea dan Vatica, famili Dipterocarpaceae. Dalam perdagangan dikenal ada beberapa jenis damar yaitu damar batu, damar abu, damar biru, damar resak, damar mata kucing, dan lain-lain. Jenis damar yang dikembangkan di Kabupaten Pesisir Barat adalah jenis damar mata kucing (namanya terambil dari warnanya getahnya yang bening seperti mata kucing) yang merupakan resin alam berasal dari hasil penyadapan pohon Shorea javanica dan merupakan komoditi ekspor yang diperdagangkan dalam bentuk alami (bongkahan getah). ${ }^{13}$

Pengelolaan damar tidak seperti hasil kebun lainnya, seperti kopi, lada, yang ditanam teratur dalam lahan kebun. Pohon damar ditanam dalam repong, yang merupakan hasil akhir dari pengolahan lahan hutan menjadi lahan pertanian yang melalui proses panjang. ${ }^{14}$ Repong ditumbuhi oleh beraneka jenis tanaman dengan jenis kayu keras dan berumur panjang, seperti duku, durian, petai, jengkol, manggis dan beragam jenis kayu yang bernilai ekonomis serta berbagai macam tanaman liar yng dibiarkan hidup. Disebut repong damar karena tanaman yang mendominasi adalah pohon damar.

\footnotetext{
${ }^{11}$ Yayan Hadiyan, Pentingnya Integrated Approach Dalam Konservasi Keragaman Jenis dan Sumberdaya Genetik. Damar Mata Kucing di Kabupaten Pesisir Barat Lampung, Prosiding Seminar Nasional Masyarakat Biodiversitas Indonesia, Vol. 1 No. 4, Juli 2015, hlm. 702

${ }^{12}$ Berdasarkan hasil wawancara dengan Bapak Albizar (Ketua Kelompok Tani Seandanan Pekon Pahmungan Kecamatan Pesisir Tengah Kabupaten Pesisir Barat), tanggal 7 April 2015

${ }_{13}$ http://www.pustekolah.org/index.php/page/24/pengembangan-hasil-penelitian, diakses tanggal 29 Agustus 2015.

${ }^{14}$ Edi Makmur dkk, "Repong Damar Bagi Masyarakat Pesisir di Kecamatan Karya Penggawa Kabupaten Pesisir Barat”, Jurnal Pendidikan dan Penelitian Sejarah, Vol. 3, No. 1, 2015, hlm. 2.
} 
Berdasarkan Surat Keputusan Menteri Kehutanan No.47/Kpts-II/1998 menyatakan bahwa areal repong damar seluas 29.000 Ha sebagai Kawasan Dengan Tujuan Istimewa (KDTI). Keputusan tersebut merupakan tonggak penting bahwa untuk pertamakalinya Pemerintah Indonesia secara resmi mengakui sistem usaha tani yang dibangun masyarakat setempat sebagai sistem pengelolaan sumber daya hutan yang lestari. Hak pengelolaan diberikan kepada 16 masyarakat adat setempat. Total areal luas repong damar tersebut dibagi atas 2 bagian yaitu 21.000 Ha terletak di luar kawasan dan 8.000 Ha berada dalam kawasan. Menurut informasi dari Kasie Kehutanan Dinas Perkebunan dan Kehutanan Kabupaten Pesisir Barat ${ }^{15}$ bahwa populasi damar yang berada di luar kawasan diperkirakan telah berkurang hingga 50\% yang diakibatkan oleh penebangan pohon damar untuk dijual kayu. Kualitas kayu damar yang termasuk jenis meranti menarik perusahaan perkayuan untuk memanfaatkan kayu pohon damar sebagai bahan baku industri shaw-mill. Kebutuhan masyarakat petani akan uang cash juga mendorong frekuensi penjualan pohon damar untuk dimanfaatkan kayunya.

Kabupaten Pesisir Barat merupakan sentra penghasil getah damar mata kucing, namun seiring dengan perubahan situasi dan kondisi masyarakat mengalami perubahan. Banyak diantara petani pemilik pohon damar menjual pohonnya untuk memenuhi kebutuhan hidup, dan karena faktor harga getah damar yang sangat fluktuatif yang mengakibatkan menurunnya tingkat keuntungan yang diperoleh petani. Meskipun demikian, damar masih banyak di budidaya di Kabupaten Pesisir Barat.Beberapa Kecamatan yang terdapat repong damar diantaranya Kecamatan Lemong, Pesisir Utara, Karya Penggawa, Pesisir Tengah, Pesisir Selatan, Ngambur, Bengkunat dan Bengkunat Belimbing masih terdapat hutan damar.

Damar Mata Kucing (shorea javanica) yang menjadi komoditi andalan atau ikon Kabupaten Pesisir Barat Propinsi Lampung dapat tumbuh dengan baik di hutan hujan tropis dengan curah hujan rata-rata $3300 \mathrm{~mm} /$ tahun. Tumbuh pada tanah kering atau tanah yang tergenang air misalnya hutan, rawa, tanah liat, tanah berpasir, maupun berbatu. Tanah tempat tumbuhnya adalah tanah yang

15 Berdasarkan hasil wawancara dengan Bapak Sapuan (Kasie Kehutanan Dinas Perkebunan dan Kehutanan Kabupaten Pesisir Barat Propinsi Lampung) pada pada tanggal 8 April 2015 
sarang, agak rapat, dan subur dengan pH antara 5,9 - 6,3. Secara topografi yang sesuai adalah daerah berbukit atau curam (ketinggian 600 sampai 1.000 meter dari permukaan laut). Kabupaten Pesisir Barat sebagai wilayah penghasil mayoritas getah damar mata kucing secara geografis terletak pada koordinat 40,40', $0^{\prime \prime}-6^{0}$, $0^{\prime}, 0^{\prime \prime}$ Lintang Selatan dan $103^{\circ}, 30^{\prime}, 0^{\prime \prime}-104^{0}, 50^{\prime}, 0^{\prime \prime}$ Bujur Timur. Memperhatikan faktor geografis, topografis dan iklim wilayah dari tanaman damar mata kucing sehingga menghasilkan getah dengan kualitas baik, maka pohon damar mata kucing apabila ditanam di wilayah lain sulit tumbuh atau tumbuh namun tidak menghasilkan getah. Faktor geografis, topografi, dan iklim sangat mempengaruhi pertumbuhan pohon dan kualitas getah yang dihasilkan.

Pohon damar dikelola dengan cara yang khas oleh masyarakat, keberadaannya sebagai repong ikut menunjang produktivitas getah damar dengan kualitas baik. Tradisi pembukaan lahan yang dilakukan oleh masyarakat Krui secara garis besar dapat dibedakan atas tiga fase produktif 16 , yaitu : fase dakhak (ladang), adalah fase ketika ladang siap tanam mulai ditanami dengan tanaman-tanaman subsistensi seperti padi atau palawija, fase kebun, adalah fase bagi tanaman muda yang mana berkebun merupakan alasan utama dalam pengambilan keputusan untuk membuka lahan hutan, dan fase repong, dimana masyarakat Krui mulai menanamkan lahan pertaniannya dengan repong apabila keragaman jenis tanaman yang tumbuh di dalamnya sudah terpenuhi, yang pada umumnya didominasi dengan tanaman keras. Proses penanaman tersebut dilakukan secara simultan semasa pemeliharaan tanaman kebun. Repong damar adalah sistem pengelolaan tanaman perkebunan yang ekosistemnya merupakan hamparan tanaman yang membentuk suatu hutan yang dikelola oleh masyarakat. ${ }^{17}$ Repong damar baru benar-benar produktif setelah berusia lebih dari 20 tahun, pada saat itu pohon damar sudah bisa ditakik untuk mendapatkan resin (getah). ${ }^{18}$

Masyarakat di Pesisir Barat, khususnya Desa Pahmungan, memiliki nilainilai atau norma-norma adat dalam pengelolaan hutan. Nilai-nilai adat

${ }^{16}$ Edi Makmur dkk, Op.Cit., hlm. 2

${ }^{17}$ Valentina Nainggolan, Analisis Populasi Jenis Primata di Repong Damar Pekon Pabmungan Kecamatan Pesisir Tengah Krui Lampung Barat, Skripsi, Bandar Lampung : Unila, 2011, hlm. 39

18Zulkifli Lubis, Repong Damar : Kajian Tentang Pengambilan Keputusan Dalam Pengelolaan Laban Hutan di Pesisir Krui Lampung Barat, Bogor : Center For International Foresty Research, 1997, hlm. 9 
masyarakat setempat dalam melestarikan hutan disebut dengan kearifan lokal.19 Salah satu kearifan lokal yang terdapat pada masyarakat di sekitar kawasan penyangga Taman Nasional Bukit Barisan Selatan (TNBBS), yakni pohon damar tidak boleh ditebang dan setiap orang yang melanggar hukum tersebut menerima hukuman dalam bentuk penanaman pohon damar baru, bahkan setiap orang yang akan menjadi calon pengantin harus menanam pohon sebelum menikah. Menurut warga ${ }^{20}$, repong damar di Pahmungan dapat terus bertahan karena warga takut "kualat" yang akan berujung malapetaka, jika menebang pohon damar yang ditanam para leluhur. Kesadaran akan pentingnya melestarikan repong damar sudah berlangsung sejak ratusan tahun lalu. Nenek moyang mereka mengajarkan nilai-nilai tradisional dalam mengelola repong damar.

\section{Kendala Damar Mata Kucing (shorea javanica) dalam Pendaftaran sebagai Indikasi Geografis}

Damar Mata Kucing (shorea javanica), seperti dijelaskan di atas, menghadapi permasalahan penurunan populasi yang mengancam keberadaan sumberdaya genetik damar sebagai material penting yang menjaga keberlangsungan jenis tersebut di masa mendatang. Degradasi repong damar dapat diantisipasi dan dikendalikan melalui konsep perlindungan kekayaan intelektual berupa Indikasi Geografis. Konsep tersebut memberikan perlindungan dari segi ekonomi dengan menjaga standarisasi kualitas dan harga getah damar, sehingga dapat mempertahankan eksistensi repong damar dan tidak menimbulkan gangguan ekologis dan keberlangsungan sosial ekonomi masyarakat dalam jangka panjang.

Indikasi geografis mempunyai nilai ekonomi yang sangat menjanjikan, yang seringkali pihak lain (negara atau daerah luar) mendapat manfaat atau keuntungan ekonomi terhadap hak indikasi geografis karena pihak lain (negara atau daerah luar) menggunakan momen perlindungan indikasi geografis, sedangkan pihak asal yang sebenarnya memiliki indikasi geografis tidak dapat berbuat banyak atas keuntungan pihak lain tersebut.Perlindungan hak indikasi

19 Ayu Winarti, Kearifan Lokal Masyarakat Pekon Pahmungan Dalam Pelestarian Repong Damar di Kawasan Penyangga Taman Nasional Bukit Barisan Selatan (TNBBS), Skripsi, Universitas Pendidikan Indonesia, Bandung, 2013, hlm. 1

${ }^{20}$ Hasil wawancara dengan Bapak Albizar (Ketua Kelompok Tani di pekon Pahmungan), tanggal 7 April 2015 
geografis sering disalahgunakan oleh beberapa pengusaha luar yang mengklim dirinya yang mempunyai hak indikasi geografis. ${ }^{21}$

Indikasi geografis mempunyai sifat eksklusif yang bertujuan agar pemilik hak dapat mengeksploitasi dan menggunakan indikasi geografis miliknya dengan rasa aman karena sebagai pemilik kekayaan mempunyai hubungan hukum dengan barang atau objek yang menjadi sasaran kepemilikannya. Sifat eksklusif hanya dapat diberikan kepada yang berhak yaitu pemilik hak atas indikasi geografis tersebut jika telah dilakukan pendaftaran. ${ }^{22}$

Pendaftaran menjadi syarat mutlak diakuinya produk dilindungi dengan menggunakan indikasi geografis. Ciri dan/atau kualitas yang menjadi dasar diberikannya perlindungan dituangkan dalam Buku Persyaratan yang juga memuat informasi tentang pengaruh lingkungan geografis, faktor alam, serta faktor manusia yang mempengaruhi kualitas atau karakteristik barang tersebut; selain itu juga mencakup informasi tentang peta wilayah, sejarah dan tradisi, proses pengolahan, metode pengujian kualitas barang, serta label yang digunakan. Buku Persyaratan tersebut penyusunannya dilakukan oleh kelompok masyarakat tempat dihasilkannya barang yang dimaksud. ${ }^{23}$

Damar Mata Kucing yang terdapat di Kabupaten Pesisir Barat memenuhi persyaratan sebagai komoditi yang dapat dilindungi melalui Kekayaan Intelektual berupa Indikasi Geografis, yakni dipengaruhi oleh faktor alam, faktor manusia maupun keduanya. Kondisi geografis, topografi yang berupa perbukitan dan curam, iklim tropis yang dominan dengan curah hujan sedang sangat mendukung produktivitas getah damar mata kucing. Faktor manusia dipengaruhi oleh cara masyarakat Pesisir Barat dalam membudidayakan repong damar yang dimulai sejak 120 tahun $^{24}$ yang lalu. Sistem repong damar yang ada di Pesisir Barat merupakan zona penyangga dari TNBBS (Taman Nasional Bukit Barisan Selatan), dimulai sekitar tahun 1700-an yang melakukan budidaya secara

${ }^{21}$ Sahlan Efendi, Perlindungan Hukum Hak Atas Indikasi Geografis, http://pn-kotabumi.go.id, diakses tanggal 15 Maret 2015

${ }^{22}$ Fitri Hidayat, Perlindungan Indikasi Geografis Terhadap Produk Potensi Indikasi Geografis di Indonesia, Tesis, Universitas Brawijaya, Malang, 2011

23Penjelasan Pasal 1 Peraturan Pemerintah No. 51 Tahun 2007 tentang Indikasi Geografis

${ }^{24}$ Wardah, Keanekaragaman Jenis Tumbuhan di Kawasan Hutan Krui, Taman Nasional Bukit Barisan Selatan Lampung Barat, Jurnal Teknologi Lingkungan, Pusat Pengkajian dan Penerapan Teknologi Lingkungan (P3LT)BPPT, Vol. 6 No. 3 September, 2005, hlm. 477 
agroforestry dimana tanaman berkayu utamanya berupa pohon-pohon damar (shorea javanica), sistem inilah yang diwariskan secara turun menurun sampai saat ini.

Indikasi Geografis memiliki sifat komunal atau kolektif yang berarti bahwa karakter kepemilikan menjadi hak (milik) bersama masyarakat yang mencakup dalam wilayah Indikasi Geografis terdaftar. Setelah mendaftarkan produk yang memiliki potensi Indikasi Geografis dan memperoleh perlindungan hukum melalui Indikasi Geografis, masyarakat tersebut memiliki hak eksklusif untuk mengedarkan dan memperdagangkan produknya sehingga masyarakat daerah lain dilarang untuk menggunakannya pada produk mereka. ${ }^{25}$

Berdasarkan pada Pasal 5 Peraturan Pemerintah No. 51 Tahun 2007 bahwa masyarakat pemegang Indikasi Geografis terdiri dari lembaga yang mewakili masyarakat di daerah yang memproduksi barang yang bersangkutan terdiri atas pihak yang mengusahan barang hasil alam atau kekayaan alam, produsen barang hasil pertanian, pembuat barang hasil kerajinan tangan atau barang hasil industri, atau pedagang yang menjual barang tersebut; lembaga yang diberi kewenangan untuk itu; dan kelompok konsumen barang tersebut. Merujuk kepada ketentuan sebagaimana disebutkan di atas, masyarakat petani atau pedagang atau konsumen Damar Mata Kucing hendaknya segera membentuk kelompok atau asosiasi pemegang hak Indikasi Geografis.

Pada tahun 1997 di Pesisir Barat (pada saat itu masih bergabung sebagai Kabupaten Lampung Barat) berdiri organisasi Persatuan Masyarakat Petani Repong Damar (PMPRD), kemudian tanggal 11 Nopember 2007 para petani dan tokoh adat 16 marga bersepakat membentuk satu organisasi petani repong selain PMPRD yaitu Persatuan Peduli Repong dan Lingkungan Hidup (PPRLH). Latar belakang berdirinya kedua organisasi tersebut adalah keinginan luhur petani damar untuk mengembalikan fungsi repong bagi kepentingan ekonomi dan lingkungan hidup setempat.Namun, sangat disayangkan keberadaan organisasi tersebut saat ini sudah tidak eksis lagi. Petani yang dulunya tergabung dalam PMPRD kembali ke kelompok tani yang ada di pekon (desa) masing-masing.

\footnotetext{
${ }^{25}$ Maria Nugraheni Oktavia, Yuliati, Yenni Eta Widyanti, Upaya Perlindungan Hukum Indikasi Geografis Terhadap Apel Batu (Studi di Dinas Koperasi, UKM, Perindustrian dan Perdagangan Kota Batu), Jurnal Hukum, http://hukum.studentjournal.ub.ac.id, 2015, hlm. 7
} 
Masyarakat di Pesisir Barat sampai saat ini belum membentuk atau menunjuk kelompok petani damar yang sudah ada untuk menjadi wakil masyarakat sebagai pemohon dalam pendaftaran Indikasi Geografis. Kondisi ini dipicu karena keterbatasan pengetahuan masyarakat berkaitan dengan manfaat pendaftaran getah damar mata kucing sebagai Indikasi Geografis, proses administrasi terutama dalam penyusunan permohonan Indikasi Geografis, maupun keterbatasan pemahaman berkaitan dengan hukum tertulis khususnya tentang kekayaan intelektual. Hal tersebut merupakan salah satu kendala belum tersusunnya Buku Persyaratan Indikasi Geografis, dalam prakteknya kelompok pemegang hak dibantu Dinas terkait dan Pemerintah Kabupaten menyusun tim untuk menyusun Buku Persyaratan Indikasi Geografis yang menjadi persyaratan dalam pendaftaran Indikasi Geografis.

Pendaftaran Indikasi Geografis harus memenuhi kriteria dan persyaratan yang ditetapkan oleh Peraturan Pemerintah No. 51 Tahun 2007 tentang Indikasi Geografis Pasal 6 yang menyatakan bahwa: (1) Permohonan harus mencantumkan persyaratan administratif yaitu: (a) Tanggal, bulan, tahun; (b) nama lengkap, kewarganegaraan, dan alamat pemohon; (c) nama lengkap dan alamat kuasa, apabila permohonan diajukan melalui kuasa. (2) Permohonan tersebut harus melampirkan: (a) surat kuasa khusus, apabila permohonan diajukan melalui kuasa; (b) surat rekomendasi dari pemerintah daerah setempat; (c) melampirkan bukti pembayaran. (3) Permohonan tersebut harus dilengkapi dengan Buku Spesifikasi yang terdiri atas: (a) nama indikasi geografis yang dimohonkan pendaftarannya; (b) nama barang yang dilindungi oleh indikasi geografis; (c) uraian mengenai karakteristik khas dan kualitas yang membedakan barang tertentu dengan barang lain yang memiliki kategori sama, dan menjelaskan tentang hubungannya dengan daerah tempat barang tersebut dihasilkan; (d) uraian mengenai pengaruh lingkungan geografis dan alam serta faktor manusia terhadap kualitas atau karakteristik barang tersebut; (e) uraian tentang batas-batas wilayah dan/atau peta daerah yang dilindungi oleh indikasi geografis; (f) uraian mengenai sejarah dan tradisi yang berhubungan dengan pemakaian indikasi geografis untuk menandai barang yang dihasilkan di daerah tersebut, termasuk pengakuan dari masyarakat mengenai indikasi geografis 
tersebut; (g) uraian yang menjelaskan tentang proses produksi, proses pengolahan, proses pembuatan yang digunakan sehingga memungkinkan setiap produsen di daerah tersebut dapat memproduksi, mengolah, atau membuat barang terkait; (h) uraian mengenai metode yang digunakan untuk menguji kualitas barang yang dihasilkan; dan (i) label yang digunakan pada barang dan memuat indikasi geografis.

Berdasarkan pada kriteria dan syarat pendaftaran Indikasi Geografis tersebut, maka untuk komoditi getah Damar Mata Kucing sama sekali belum memiliki syarat-syarat yang dimaksud. Petani dan Dinas Perkebunan dan Kehutanan Kabupaten Pesisir Barat kesulitan dalam menyusun Buku Persyaratan yang dimaksud karena terbatasnya sosialisasi berkaitan dengan tata cara penyusunan Buku Persyaratan Indikasi Geografis, selain itu minimnya dukungan dana bagi kegiatan pendaftaran komoditi juga berperan sebagai faktor penghambat proses pendaftaran Damar Mata Kucing (shorea javanica) sebagai Indikasi Geografis.

Pengajuan pendaftaran Indikasi Geografis dapat dilakukan melalui tiga cara yakni pemohon dapat mengajukan langsung ke Direktorat Jenderal Hak Kekayaan Intelektual, melalui Kantor Wilayah Kementerian Hukum dan Hak Asasi Manusia R.I di seluruh Indonesia, atau melalui Kuasa Hukum Konsultan HKI terdaftar. Pada prinsipnya Kanwil Hukum dan HAM, khususnya di wilayah Lampung, dapat menerima permohonan pendaftaran Hak Kekayaan Intelektual karena instansi ini sebagai salah satu pilar pendukung pengembangan sistem HKI nasional sehingga mempunyai peran penting dan strategis dalam membantu melaksanakan sebagian tugas Dirjen HKI khususnya untuk mendukung dan memperlancar proses pengajuan permohonan yang berasal dari daerah masingmasing mengingat dalam melaksanakan pembangunan dan pengembangan sistem HKI nasional merupakan tugas dan tanggung jawab yang tidak hanya dibebankan kepada Dirjen HKI semata, akan tetapi perlu didukung oleh Kantor Wilayah Kementerian Hukum dan HAM Se-Indonesia agar dapat menjadi ujung tombak dalam melaksanakan pemberian layanan hukum di bidang HKI secara maksimal, efektif dan efisien di daerah masing-masing. Namun, dalam implementasinya Kanwil Hukum dan HAM wilayah Lampung tidak terlibat 
dalam proses pendaftaran Indikasi Geografis. ${ }^{26}$ Proses pengajuan permohonan Indikasi Geografis diajukan pemohon langsung ke Direktorat Jendral Hak Kekayaan Intelektual, hal tersebut dilakukan untuk mempersingkat proses, karena Kanwil Hukum dan HAM Lampung hanya menampung permohonan sedangkan yang akan memproses lebih lanjut diserahkan sepenuhnya kepada Dirjen HKI.

Urgensi pendaftaran Indikasi Geografis sangat terkait dengan berbagai pihak antara lain bagi petani maupun pedagang yaitu melindungi komoditinya supaya terhindar dari pengakuan oleh pihak lain secara melawan hukum, bagi konsumen yaitu terpenuhinya hak-hak konsumen yaitu hak atas kenyamanan, keamanan dan keselamatan dalam mengkonsumsi barang dan/atau jasa; hak untuk memilih barang dan/atau jasa serta mendapatkan barang dan/atau jasa tersebut sesuai dengan nilai tukar dan kondisi serta jaminan yang dijanjikan; hak atas informasi yang benar, jelas dan jujur mengenai kondisi dan jaminan barang dan/atau jasa. ${ }^{27}$

Perlindungan Indikasi Geografis memberikan manfaat, ${ }^{28}$ antara lain: (1) memberikan perlindungan hukum pada produk Indikasi Geografis di Indonesia, (2) Indikasi Geografis dapat digunakan sebagai strategi pemasaran produk Indikasi Geografis pada perdagangan dalam dan luar negeri, (3) memberikan nilai tambah pada produk berpotensi Indikasi Geografis di daerah dan meningkatkan kemampuan ekonomi daerah, (4) meningkatkan reputasi produk Indikasi Geografis pada perdagangan global, (5) adanya persamaan perlakuan atas perlindungan Indikasi Geografis dan promosi Indikasi Geografis di luar negeri, (6) Indikasi Geografis sebagai salah satu alat untuk menghindari persaingan curang.

Dalam pendaftaran Indiksi Geografis Damar Mata Kucing, persyaratan yang harus menjadi perhatian bagi pemohon adalah: 1. pihak atau lembaga yang dapat melakukan pendaftaran Indikasi Geografis; 2. menyusun buku persyaratan

\footnotetext{
26 Berdasarkan wawancara dengan Bapak Masriakromi (Kepala Divisi Pelayanan Hukum dan HAM Lampung) Pada tanggal 1 Juni 2015.

${ }^{27}$ Zakiyah, "Urgensi Perlindungan Hak Kekayaan Intelektual Indikasi Geografis Bagi Konsumen", Jurnal Legitimitas, Vol. II No. 1 Tahun 2014, hlm. 115

${ }^{28}$ Tatty Aryani Ramli dkk, "Urgensi Pendaftaran Indikasi Geografis Ubi Cilembu Untuk Meningkatkan IPM”, Jurnal Mimbar, Vol. XXVI No. 1 Tahun 2010, hlm. 85.
} 
Indikasi Geografis, dan 3. memenuhi ketentuan syarat administrasi pendaftaran sebagaimana tercantum dalam Peraturan Pemerintah No. 51 Tahun 2007.

Keberadaan Pemerintah Kabupaten Pesisir Barat merupakan ujung tombak bagi terlindunginya potensi komoditi Damar Mata Kucing (shorea javanica) yang memiliki karakteristik unik sebagai indikasi geografis. Biaya mahal dalam pembuatan dan penyusunan Buku Persyaratan yang cukup rumit merupakan salah satu kendala dalam pengajuan permohonan pendaftaran indikasi geografis. Dalam penyusunan Buku Persyaratan diperlukan penelitian di laboratorium untuk mengetahui karakteristik kandungan dari komoditi damar mata kucing, selain itu penelusuran sejarah dan karakteristik yang dipengaruhi oleh manusia juga memerlukan diskusi yang mendalam untuk melengkapi ketentuan dalam Buku Persyaratan. Kondisi inilah yang memerlukan kepedulian dari Pemerintah di Kabupaten terhadap komoditi yang memiliki karakteristik khas indikasi geografis, sehingga perlindungan dapat diberikan untuk mengantisipasi hal-hal negatif yang tidak diinginkan.

\section{Upaya Pemerintah Daerah Kabupaten Pesisir Barat Melindungi Damar Mata Kucing (shorea javanica) sebagai Wujud Pelestarian Kawasan Hutan dan Peningkatan Taraf Hidup Petani}

Sejak masa Kolonial Belanda, getah Damar Mata Kucing, namanya diambil dari warna getahnya yang bening seperti mata kucing, dari wilayah Pesisir Barat Lampung terkenal di dunia. Pohon damar ditanam oleh leluhur warga desa sejak 1829 dan di masanya pernah menjadi komoditas primadona yang terkenal. Hingga kini, wilayah ini terus menghasilkan getah damar, seperti Kecamatan Pesisir Utara, Pesisir Tengah, Karya Pengawa, Ngambur, Bengkunat dan Pesisir Selatan.

Salah satu penghasil damar adalah di Pekon (desa) Pahmungan, Kecamatan Pesisir Tengah,yang memiliki luas wilayah sekitar 2.500 hektar, dengan luas repong, istilah untuk kebun-hutan damar, adalah sekitar seribu hektar. Di Desa Pahmungan, banyak pohon damar yang merupakan hasil warisan dari generasi sebelumnya. Sepetak kebun damar biasanya diwariskan kepada anak tertua. Seorang anak yang tidak diwarisi kebun akan membuka lahan baru untuk 
dijadikan kebun damar. ${ }^{29}$ Dahulu bahkan repong damar menjadi simbol status kepemililikan tanah oleh masyarakat Krui dimana tanah hutan yang sudah dibuka oleh seseorang tidak akan bisa lagi digugat oleh yang lainnya bila tanah bekas hutan tersebut sudah berwujud repong damar.Sebagian besar warga Pahmungan bekerja sebagai petani, bahkan perempuan di Pahmungan sangat lihai memanjat pohon damar. Getah damar menjadi sumber pendapatan utama, karena getah dapat dipanen dan dijual tiap saat untuk mencukupi kebutuhan hidup masyarakat. Berbeda dengan komoditi lainnya, seperti kopi dan lada yang hanya bisa dipanen setahun sekali.

Ancaman terbesar terhadap repong damar adalah konversi lahan menjadi peruntukan lain. Hal ini disebabkan belum diakuinya status kepemilikan tanah masyarakat setempat selaku pemilik repong damar oleh pemerintah sehingga kawasan ini rentan terhadap tekanan dari luar seperti keinginan untuk membangun perkebunan kelapa sawit. Salah satunya adalah alih fungsi lahan menjadi perkebunan inti rakyat (PIR) sawit sejak 1995 seluas 25.000 ha oleh PT Karya Canggih Mandiri Utama (KCMU). Selain itu, beberapa petani tergiur untuk mengganti repong damarnya dengan tanaman lain yang lebih menjanjikan, seperti cengkeh, kopi, maupun lada. Disamping itu, nilai dan rasa kebanggaan memiliki repong damar sebagai warisan nenek moyang mulai pudar. Banyak kaum muda yang lebih suka meninggalkan desa untuk mencari pekerjaan sebagai karyawan pabrik daripada bertani atau mengurus repong damar.

Ancaman lainnya yaitu pesatnya perkembangan teknologi. Hal ini dapat di lihat dari munculnya bahan sintetis pengganti resin yang mengakibatkan menurunnya posisi tawar komoditas damar di pasar global. Selain itu, desakan kebutuhan hidup membuat para petani mulai tergiur untuk menjual kayu damar karena harganya yang cukup tinggi jika dibandingkan dengan harga getah damar. Walaupun ancaman-ancaman seperti yang telah dijelaskan diatas datang setiap saat, namun repong damar masih tetap bertahan. Di saat Indonesia dihadapkan pada parahnya kerusakan hutan karena illegal logging yang meskipun secara ekonomi lebih menggiurkan, masyarakat Pekon Pahmungan justru memilih untuk menjaga kebun damarnya yang menyerupai hutan alam tersebut. Berbagai 
permasalahan yang dihadapi dalam mengelola damarnya, tidak lantas membuat petani damar Pesisir Barat serta merta meninggalkan kebun damar dan beralih usaha. Petani damar mempertahankan repong damarnya dengan menerapkan nilai-nilai kearifan lokal yang ada. ${ }^{30}$

Penebangan pohon damar yang dilakukan masyarakat didasari beberapa alasan, antara lain serangan hama dan penyakit, konversi repong damar menjadi kebun kelapa sawit, dan memenuhi kebutuhan ekonomi. Dalam rangka mengatasi permasalahan tersebut, Pemerintah telah melakukan pembatasan penebangan pohon damar mata kucing di Provinsi Lampung melalui Surat Keputusan Menteri Kehutanan Nomor S.459/Menhut-VI/2010, namun implementasinya belum berjalan dengan baik. Masyarakat tetap melakukan penebangan liar terhadap pohon Damar Mata Kucing, meskipun ada larangan penebangan pohon. Hal demikian terjadi karena belum ada solusi bagi masyarakat untuk mengatasi permasalahan ekonomi.

Dinas Kehutanan Propinsi Lampung31 telah melakukan upaya dalam rangka menjaga kelestarian pohon Damar Mata Kucing dan meningkatkan produktivitas getah melalui pembinaan, bimbingan, dan penyuluhan kepada petani damar terkait budidaya. Bantuan bibit unggul juga dilakukan Dinas Kehutanan untuk melakukan peremajaan pohon. Kegiatan pembinaan dan penyuluhan lebih intensif dilakukan oleh Dinas Perkebunan dan Kehutanan Kabupaten Pesisir Barat.

Melihat fenomena yang mengkhawatirkan tersebut, Pemerintah Kabupaten Pesisir Barat berinisiatif untuk mengajukan Raperda untuk melarang penebangan pohon damar dan memberikan jalan keluar yang terkait pemenuhan kebutuhan ekonomi masyarakat. Dalam Raperda tersebut nantinya juga mengatur tentang lembaga keuangan Kabupaten yang membantu masyarakat petani damar secara ekonomi, dengan konsepbagi masyarakat yang membutuhkan dana dapat menjual pohon damar kepada Pemerintah, namun masyarakat tetap dapat mengambil manfaat dari getah pohon damar dengan sistem bagi hasil $60 \%$ bagi petani yang mengelola dan $40 \%$ bagi pemerintah daerah. Sebenarnya Raperda

${ }^{30}$ Ayu Winarti, op.cit., hlm. 3

31 Berdasarkan wawancara dengan Ibu Eny Puspitasari, S.Hut Kepala Seksi Perhutanan Masyarakat pada Bidang Rehabilitasi dan Reklamasi Hutan Dinas Kehutanan Provinsi Lampung pada tanggal 29 April 2015. 
tersebut dirancang sejak Kabupaten Pesisir Barat masih bergabung dengan Kabupaten Lampung Barat. Pemerintah Kabupaten Lampung Barat melalui Dinas Kehutanan merancang Peraturan Daerah (Perda) tentang pengelolaan dan pemanfaatan damar sebagai bentuk kepedulian terhadap pelestarian alam di daerah itu. Peraturan daerah yang akan dirancang tersebut, sebagai langkah pemerintah untuk melestarikan tanaman damar di Lampung Barat agar tidak berkurang jumlah dan populasinya. Raperda tentang Pengelolaan dan Pelestarian Pohon Damar itu akan dimasukan Rancangan Perda Pengelolaan Sumber Daya Hutan.

Pada tanggal 25 Oktober 2012 Kabupaten Pesisir Barat telah sah menjadi Kabupaten hasil pemekaran dari Lampung Barat berdasarkan Undang-Undang No. 22 Tahun 2012 (Lembaran Negara nomor 231, Tambahan Lembaran Negara Nomor 5364) tentang Pembentukan Daerah Otonomi Baru (DOB) Kabupaten Pesisir Barat Provinsi Lampung. Dengan adanya pemekaran wilayah tersebut, repong damar masuk dalam wilayah Kabupaten Pesisir Barat, sehingga kelanjutan pembahasan Raperda yang berkaitan dengan pelestarian damar menjadi kewenangan Pesisir Barat untuk dijadikan Perda di wilayahnya.

Pesisir Barat sebagai kabupaten baru hasil pemekaran menghadapi kendala dalam penetapan Raperda yang telah dirancang tersebut, yakni berkaitan dengan pejabat kepala daerah dan kelengkapan struktur pemerintahan, selain itu belum mempunyai APBD (anggaran pendapatan belanja daerah). Keseluruhan kebijakan (termasuk penetapan Raperda damar) menunggu struktur pemerintahan yang lengkap dan definitif.

Raperda tentang Pengelolaan dan Pelestarian Pohon Damar merupakan awal langkah yang tepat untuk kelestarian lingkungan. Pohon damar Pinus tradisional memiliki nilai tinggi, selain sebagai daerah resapan air, repong damar juga berfungsi sebagai daerah penyangga bagi upaya konservasi di Taman Nasional Bukit Barisan Selatan (TNBBS). Melestarikan repong damar tidaklah mudah bagi masyarakat Pesisir Barat, tanpa pengawasan, repong damar mungkin akan lenyap. Datangnya budaya modern, telah menggoda pemuda di Krui untuk bekerja di kota-kota besar dan industri yang kemudian meninggalkan repong damar. 
Langkah selanjutnya yang harus dilakukan adalah menstabilkan harga getah damar yang memiliki kecenderungan sangat fluktuatif, tidak ada patokan pasti dalam penentuan harga getah Damar Mata Kucing. Menurut hasil wawancara dengan petani dan pengepul damar di Desa Pahmungan, harga getah damar ditentukan oleh agen di Krui dan di Jakarta. Para petani dan pengepul di desa bahkan tidak mengetahui harga sebenarnya getah Damar Mata Kucing di pasar dalam negeri maupun untuk ekspor. ${ }^{32}$

Harga damar berbanding lurus dengan jenis atau kualitas damar, di tingkat petani getah damar sangat bervariatif kualitasnya mulai dari tingkat eksport dengan kualitas A sampai debu damar mempunyai harga jual. Hasil dari getah damar mutunya bervariasi karena tergantung dari hasil kegiatan sortir, yaitu kegiatan memilah damar berdasarkan kualitasnya. Kualitas getah dammar dan harga jual dibedakan sebagai berikut: 33

\begin{tabular}{|c|c|c|c|}
\hline No & $\begin{array}{c}\text { Jenis } \\
\text { damar } \\
\text { (kualitas) }\end{array}$ & Harga & Keterangan Fisik \\
\hline 1. & A & Rp. 25.000/kg & $\begin{array}{l}\text { Warna kuning bening dan merupakan } \\
\text { bongkahan besar (berukuran } 3 \mathrm{~cm} \times 3 \mathrm{~cm} \text { atau } \\
\text { lebih), biasanya pengambilannya berumur lebih } \\
\text { dari } 30 \text { hari. }\end{array}$ \\
\hline 2. & B & Rp. $24.000 / \mathrm{kg}$ & $\begin{array}{l}\text { Getah damar kuning bening dan merupakan } \\
\text { bongkahan yang agak kecil (berukuran } 2 \mathrm{~cm} \times 2 \\
\mathrm{~cm} \text { atau lebih), pengambilannya antara } 3-4 \\
\text { minggu. }\end{array}$ \\
\hline 2. & $\mathrm{AB}$ & Rp. 23.000/kg & $\begin{array}{l}\text { warna kuning agak kehitaman, merupakan } \\
\text { bongkahan berukuran } 2 \mathrm{~cm} \times 2 \mathrm{~cm} \text { atau lebih }\end{array}$ \\
\hline 2. & $\begin{array}{l}\text { Semi } \\
\text { (campura } \\
\text { n A, B, C) }\end{array}$ & Rp. 20.000/kg & $\begin{array}{l}\text { Warna kuning bening terdiri dari bongkahan } \\
\text { besar, sedang dan kecil) }\end{array}$ \\
\hline 3. & $\mathrm{AC}$ & Rp. $16.000 / \mathrm{kg}$ & $\begin{array}{l}\text { warna kehitam-hitaman dan berupa butiran } \\
\text { kecil }\end{array}$ \\
\hline 4. & CK & Rp. $10.000 / \mathrm{kg}$ & Warna kehitaman dengan butiran kecil \\
\hline 5. & D2 & Rp. $6.000 / \mathrm{kg}$ & Warna kehitaman butiran sangat kecil \\
\hline 6. & EE & Rp. $6.000 / \mathrm{kg}$ & Warna kehitaman butiran sangat kecil \\
\hline 7. & Debu & Rp. $5.000 / \mathrm{kg}$ & Kualitas Debu: damar berwujud debu \\
\hline
\end{tabular}

Sumber : wawancara dengan petani di Desa Pahmungan pada tanggal 8 April 2015

\footnotetext{
${ }^{32}$ Hasil wawancara dengan Pak Nurdin, Pak Albizar dan para petani Damar Mata Kucing bertempat di gudang damar pekon Pahmungan, pada tanggal 7 April 2015.
} 
Pengaruh kualitas sangat menentukan harga jual getah damar di pasaran, kualitas getah damar ditentukan oleh perlakuan petani terhadap getah. Apabila masa panen semakin lama, maka getah yang ada di pohon semakin banyak dan kualitas semakin baik. Namun, terdapat berbagai faktor yang mempengaruhi masa panen salah satunya adalah kebutuhan ekonomi petani. Hasil penjualan getah damar merupakan mata pencaharian utama bagi sebagian masyarakat di Krui, oleh karena itu terkadang petani terlalu cepat mengambil getah (panen) damar di pohon untuk segera dijual.

Harga getah damar juga dipengaruhi oleh rantai perdagangan mulai dari repong sampai siap ekspor ke luar negeri. Rantai tata niaga mulai dari penduduk dan beberapa pedagang, melalui Pasar Krui, menuju Bandar Lampung dan kemudian ke Jakarta selanjutnya siap ekspor ke negara tujuan. Rantai perdagangan ini dapat dibagi menjadi beberapa tahapan, yang masing-masing ditandai dengan adanya agen. Dari kebun, petani dapat menjual hasil ke pembeli di kebun atau lebih dikenal dengan sebutan penghadang atau ada juga petani yang mengumpulkan dahulu hasil panennya dan menjualnya pada pembeli di desa atau pengumpul. Di pekon (desa) penghasil damar umumnya terdapat 5 sampai 10 pengumpul yang mayoritas juga mempunyai kebun damar. Di desa, beberapa pedagang damar mengumpulkan produksi harian dai kebun atau pedagang pengumpul, mengeringkan dan kemudian menjual ke pedagang besar di Pasar Krui atau kepada agen yang langsung membawanya ke Jakarta. Pedagang yang ada di desa sering melakukan sortasi awal untuk mendapatkan damar dengan kualitas baik, sedang dan rendah. ${ }^{34}$

Agen-agen di Pasar Krui mengumpulkan damar dari seluruh daerah pesisir Krui dan membawa ke Bandar Lampung. Di Tanjung Karang damar dijual kepada para eksportir, pabrik-pabrik atau agen-agen lain yang membawa damar ke berbagai tujuan di pulau Jawa. Tata niaga damar sejak di repong sampai ke pengguna (baik pasar dalam negeri maupun ekspor) melibatkan banyak pihak, oleh karena itu mempengaruhi nilai jual. Berdasarkan hasil wawancara dengan petani, proses penjualan damar sebagaimana di atas sudah berlangsung lama. Petani atau kelompok tani tidak dapat memotong rantai tata niaga langsung ke

${ }^{34}$ Berdasarkan wawancara dengan Pak Albizar di Pekon Pahmungan pada tanggal 7 April 2015 
pedagang besar di Pasar Krui apalagi langsung ke Bandar Lampung. Apabila harga damar rendah, seringkali terjadi kecurangan di tingkat pengumpul atau pedagang besar yang pada akhirnya mempengaruhi kualitas damar contohnya getah damar dicampur pasir atau tepung untuk meningkatkan kuantitas damar agar meningkatkan pendapatan. Sampai saat ini belum ada standarisasi harga damar, sehingga dengan kondisi harga yang fluktuatif akan merugikan petani dan memberikan keuntungan pihak pedagang besar.

Dalam rangka mengatur getah damar warga di desa (pekon) Pahmungan sempat mewacanakan untuk membentuk bank desa yang digunakan untuk membeli dan menyalurkan getah damar yang dihasilkan warga dengan harga standard, dan tidak akan menjual getah damar dengan harga rendah kepada para agen. Dengan demikian petani tidak lagi dipermainkan oleh agen, namun karena terbentur modal, ide ini belum berlanjut. Mempertimbangkan kondisi harga damar, dan wilayah repong damar yang ada perlu komitmen semua pihak baik petani, pedagang, dan Pemerintah melalui Dinas terkait untuk mengatur harga. ${ }^{35}$ Konsep perlindungan Indikasi Geografis terhadap Damar Mata Kucing dapat dijadikan solusi untuk mengatur standarisasi harga dan kualitas damar agar terjaga dan dapat bermanfaat bagi kelestarian lingkungan dan ekonomi bagi masyarakat.

Harga getah Damar Mata Kucing (shorea javanica) pada saat ini ditentukan oleh para pedagang besar dan eksportir tanpa ada standarisasi harga, kondisi inilah yang memerlukan perhatian dari berbagai pihak terutama Pemerintah untuk melindungi petani damar. Indikasi Geografis, yang merupakan bagian dari kekayaan intelektual yang bersifat komunal menjadi solusi dalam mengatasi permasalahan standarisasi harga getah Damar Mata Kucing (shorea javanica). Perlindungan Indikasi Geografis terhadap Damar Mata Kucing, secara nasional maupun internasional, sangat diperlukan karena dapat memberikan berbagai manfaat diantaranya :36 1 . Indikasi Geografis dapat digunakan sebagai strategi pemasaran produk pada perdagangan dalam dan luar negeri; 2. Memberikan nilai

\footnotetext{
${ }^{35}$ Berdasarkan Wawancara dengan Pak Sapuan (Kasie Kehutanan Dinas Perkebunan dan Kehutanan Kabupaten Pesisir Barat Propinsi Lampung) pada pada tanggal 8 April 2015

${ }^{36}$ Indra Rahmatullah, "Perlindungan Indikasi Geografis Dalam Hak Kekayaan Intelektual (HKI) Melalui Ratifikasi Perjanjian Lisabon”, Jurnal Cita Hukum, Vol. I No. 2 Desember 2014, hlm. 308.
} 
tambah terhadap produk dan meningkatkan kesejahteraan pembuatnya; 3 . Meningkatkan reputasi produk Indikasi Geografis dalam perdagangan internasional; 4. Persamaan perlakuan sebagai akibat promosi dari luar negeri, dan 5. Perlindungan Indikasi Geografis sebagai salah satu alat untuk menghindari persaingan curang.

Komoditi atau produk yang mendapatkan sertifikasi Indikasi Geografis memiliki standarisasi harga dan kualitas yang ditunjukkan dalam buku persyaratan Indikasi Geografis suatu produk. Hak Indikasi Geografis memberi implikasi bahwa pemilik hak (pihak yang melakukan pendaftaran) akan menikmati hak eksklusif berupa hak ekonomi. Penggunaan hak ekonomi ini dapat dipertahankan dari orang ke-tiga untuk mendapatkan keuntungan ekonomi melalui hak menjual, hak memproduksi, hak menyewakan, dan hak mewariskan. ${ }^{37}$ Perlindungan tersebut baru dapat diberikan setelah dilakukan pendaftaran oleh pihak/lembaga yang mempunyai kewenangan untuk mengajukan permohonan ke Direktoran Jendral HKI.

Memperhatikan pentingnya perlindungan Indikasi Geografis terhadap komoditi getah Damar Mata Kucing hendaknya Pemerintah Kabupaten Pesisir Barat dapat segera bertindak pro-aktif untuk mengajukan permohonan Indikasi Geografis damar mata kucing yang merupakan komoditi asli dari Krui Kabupaten Pesisir Barat. Langkah-langkah konkrit yang dapat dilakukan adalah: 1. inventarisasi wilayah yang berpotensi sebagai penghasil getah Damar Mata Kucing (shorea javanica); 2. membentuk atau menunjuk lembaga yang diberi wewenang untuk melakukan pendaftaran Indikasi Geografis komoditi damar mata kucing; 3. inventarisasi data lengkap mengenai profil produk/komoditi (damar mata kucing) yang nantinya bermanfaat ketika menyusun buku riwayat atau spesifikasi yang berisi uraian secara terperinci mengenai karakteristik khas dan kualitas yang membedakan barang yang akan dilindungi dengan barang lain yang memiliki kategori sama sebagai pra-syarat pendaftaran; 4. penyuluhan hukum tentang manfaat Indikasi Geografis dan tata cara pendaftaran, sehingga memberikan pemahaman kepada masyarakat maupun stakeholder yang berkaitan dengan proses pendaftaran.

${ }^{37}$ Tatty Aryani Ramli dkk, Op.Cit., hlm. 82. 
Lembaga atau pihak yang mengajukan pendaftaran Indikasi Geografis adalah pihak yang mewakili masyarakat yang ada di daerah, baik lembaga pemerintah atau lembaga resmi lainnya seperti koperasi atau asosiasi. Dinas Perkebunan dan Kehutanan dapat melakukan pendampingan kepada petani untuk membantu pembentukan lembaga yang nantinya dapat mewakili pendaftaran Indikasi Geografis Damar Mata Kucing, lembaga tersebut nantinya sebagai pemegang hak atas Indikasi Geografis yang telah didaftarkan.

\section{Penutup}

Berdasarkan pemaparan di atas dapat disimpulkan bahwa: pertama, damar mata kucing sebagai komoditi unggulan Kabupaten Pesisir Barat yang berpotensi Indikasi Geografis sampai sekarang belum didaftarkan ke Direktorat Jendral Hak Kekayaan Intelektual karena stakeholder (petani, pedagang, Pemerintah Kabupaten) belum memahami dan menyadari urgensi serta manfaat pendaftaran Indikasi Geografis getah Damar Mata Kucing, tidak mengetahui proses administrasi terutama dalam penyusunan permohonan Indikasi Geografis, belum memiliki kelembagaan Damar Mata Kucing, maupun keterbatasan pemahaman berkaitan dengan hukum tertulis khususnya tentang kekayaan intelektual. Kedua, upaya yang telah dilakukan Pemerintah Kabupaten Pesisir Barat untuk melindungi Damar Mata Kucing (shorea javanica) sebagai wujud pelestarian kawasan hutan yakni melakukan pembatasan penebangan pohon damar mata kucing di Provinsi Lampung melalui Surat Keputusan Menteri Kehutanan Nomor S.459/Menhut-VI/2010, namun implementasinya belum berjalan dengan baik karena dalam Surat Keputusan tersebut tidak mempunyai konsekuensi hukum. Selanjutnya, Pemerintah Kabupaten Pesisir Barat berinisiatif untuk mengajukan Raperda untuk melarang penebangan pohon damar dan memberikan jalan keluar yang terkait pemenuhan kebutuhan ekonomi masyarakat. Raperda tersebut sekarang masih menunggu kelengkapan struktur organisasi Pemerintahan di Pesisir Barat, dan masih dalam pembahasan. Dalam hal perlindungan harga getah damar dalam rangka perlindungan taraf hidup petani, Pemerintah belum melakukan upaya untuk memberikan standarisasi harga dan kualitas. 
Saran yang dapat peneliti berikan dalam penelitian ini bahwa Pertama, hendaknya perlu secepatnya di sahkan Raperda tentang perlindungan pohon damar mata kucing. Kedua, Pemerintah Kabupaten hendaknya memberikan sosialisasi mengenai arti penting pendaftara Indikasi Geografis terhadap getah damar mata kucing sehingga dapat melindungi harga dan kualitasnya, serta memfasilitasi masyarakat dalam pembentukkan organisasi pemegang hak Indikasi Geografis getah damar mata kucing dan mempersiapkan persyaratan pendaftaran.

\section{Daftar Pustaka}

Agus Kurniawan, I Gede, Pengaturan Penghentian Pemakaian Indikasi Geografis Pada Merek Terdaftar Oleh Pihak Lain yang Tidak Berhak (Studi Komparatis Beberapa Negara), Tesis, Universitas Udayana, Denpasar, 2013.

Aryani Ramli, Tatty, dkk, Urgensi Pendaftaran Indikasi Geografis Ubi Cilembu Untuk Meningkatkan IPM, Jurnal Mimbar, Vol. XXVI No. 1 Tahun 2010.

Efendi, Sahlan, Perlindungan Hukum Hak Atas Indikasi Geografis, http://pnkotabumi.go.id, diakses tanggal 15 Maret 2015.

Ellyanti, dkk, “Analisis Indikasi Geografis Kopi Arabika Gayo Ditinjau Dari Rencana Tata Ruang Wilayah Kabupaten”, Jurnal Agrista Vol. 16 No. 2012.

Hadiyan, Yayan, Pentingnya Integrated Approach Dalam Konservasi Keragaman Jenis dan Sumberdaya Genetik Damar Mata Kucing di Kabupaten Pesisir Barat Lampung, Prosiding Seminar Nasional Masyarakat Biodiversitas Indonesia, Vol. 1 No. 4, Juli 2015.

Hariwijaya, M., Metodologi dan Teknik Penulisan Skripsi, Tesis, dan Disertasi, Penerbit Elemantera Publishing, Yogyakarta, 2007.

Hidayat, Fitri, Perlindungan Indikasi Geografis Terhadap Produk Potensi Indikasi Geografis di Indonesia, Tesis, Universitas Brawijaya, Malang, 2011.

Kadir Muhammad, Abdul, Hukum dan Penelitian Hukum, Cet.1 Penerbit PT. Citra Aditya Bhakti, Bandung, 2004.

Lubis, Zulkifli, Repong Damar: Kajian Tentang Pengambilan Keputusan Dalam Pengelolaan Lahan Hutan di Pesisir Krui Lampung Barat, Bogor : Center For International Foresty Research, 1997.

Makmur, Edi, dkk, Repong Damar Bagi Masyarakat Pesisir di Kecamatan Karya Penggawa Kabupaten Pesisir Barat, Jurnal Pendidikan dan Penelitian Sejarah, Vol. 3 No. 1, 2015. 
Nainggolan, Valentina, Analisis Populasi Jenis Primata di Repong Damar Pekon Pahmungan Kecamatan Pesisir Tengah Krui Lampung Barat, Skripsi, Bandar Lampung, Unila, 2011.

Nugraheni Oktavia, Maria, Yuliati, Yenni Eta Widyanti, Upaya Perlindungan Hukum Indikasi Geografis Terhadap Apel Batu (Studi di Dinas Koperasi, UKM, Perindustrian dan Perdagangan Kota Batu), Jurnal Hukum, http://hukum.studentjournal.ub.ac.id, 2015.

Rahmatullah, Indra, Perlindungan Indikasi Geografis Dalam Hak Kekayaan Intelektual (HKI) Melalui Ratifikasi Perjanjian Lisabon, Jurnal Cita Hukum, Vol. I No. 2 Desember 2014.

Risang Ayu, Miranda, Memperbincangkan Hak Kekayaan Intelektual : Indikasi Geografis, PT. Alumni ,Bandung, 2006.

Sumiati, Yeti, dkk, Kajian Yuridis Sosiologis Mengenai Indikasi Geografis Sebagai Sumber Pendapatan Asli Daerah (PAD), Mimbar Vol. 24 No.1, Januari 2008.

Wardah, Keanekaragaman Jenis Tumbuhan di Kawasan Hutan Krui, Taman Nasional Bukit Barisan Selatan Lampung Barat, Jurnal Teknologi Lingkungan, Pusat Pengkajian dan Penerapan Teknologi Lingkungan (P3LT)- BPPT, Vol. 6 No. 3 September, 2005.

Winarti, Ayu, Kearifan Lokal Masyarakat Pekon Pahmungan Dalam Pelestarian Repong Damar di Kawasan Penyangga Taman Nasional Bukit Barisan Selatan (TNBBS), Skripsi, Universitas Pendidikan Indonesia, Bandung, 2013.

Zakiyah, Urgensi Perlindungan Hak Kekayaan Intelektual Indikasi Geografis Bagi Konsumen, Jurnal Legitimitas, Vol. II No. 1 Tahun 2014.

http:/ / epetani.deptan.go.id/berita, diakses tgl.20-1-2014.

http://www.disbun.baliprov.go.id, diakses tgl.26 April 2015.

http://www.wipo.int/geo_indications/en/about.html, diakses tanggal 10 Maret 2015.

http://www.pustekolah.org/index.php/page/24/pengembangan-hasil-

penelitian, diakses tanggal 29 Agustus 2015 